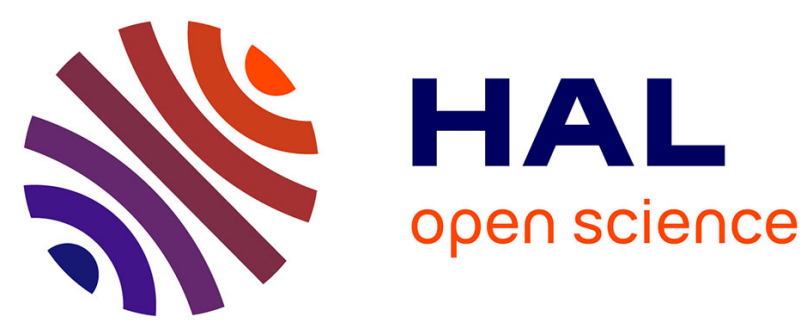

\title{
Contribution of AMS measurements in understanding the migmatitic terrains of Pointe Géologie, Terre Adélie (East-Antarctica)
}

Jerôme Bascou, Bernard Henry, René-Pierre Ménot, Minoru Funaki, Guilhem Barruol

\section{To cite this version:}

Jerôme Bascou, Bernard Henry, René-Pierre Ménot, Minoru Funaki, Guilhem Barruol. Contribution of AMS measurements in understanding the migmatitic terrains of Pointe Géologie, Terre Adélie (EastAntarctica). Tectonophysics, 2013, 603, pp.123-135. 10.1016/j.tecto.2013.05.021 . hal-01304296

\section{HAL Id: hal-01304296 \\ https://hal.univ-reunion.fr/hal-01304296}

Submitted on 21 Apr 2016

HAL is a multi-disciplinary open access archive for the deposit and dissemination of scientific research documents, whether they are published or not. The documents may come from teaching and research institutions in France or abroad, or from public or private research centers.
L'archive ouverte pluridisciplinaire $\mathbf{H A L}$, est destinée au dépôt et à la diffusion de documents scientifiques de niveau recherche, publiés ou non, émanant des établissements d'enseignement et de recherche français ou étrangers, des laboratoires publics ou privés. 


\title{
Contribution of AMS measurements in understanding the migmatitic terrains of Pointe Géologie, Terre Adélie (East-Antarctica)
}

\author{
Jérôme Bascou ${ }^{\mathrm{a}, *}$, Bernard Henry $^{\mathrm{b}}$, René-Pierre Ménot ${ }^{\mathrm{a}}$, Minoru Funaki ${ }^{\mathrm{c}}$, Guilhem Barruol ${ }^{\mathrm{d}}$ \\ a Université de Lyon, Université Jean Monnet and UMR-CNRS 6524, Laboratoire Magmas et Volcans, 23 rue du Dr Paul Michelon, 42023 Saint Etienne, France \\ b Paléomagnétisme, Institut de Physique du Globe de Paris, Sorbonne Paris Cité, Université Paris Diderot and UMR-CNRS 7154, 4 avenue de Neptune, 94107 Saint-Maur cedex, France \\ ${ }^{c}$ National Institute of Polar Research, 10-3 Midori-cho, Tachikawa, Tokyo 190-8518, Japan \\ ' Université de la Réunion, CNRS and Institut de Physique du Globe de Paris, Géosciences Réunion, 97744 Saint Denis, cedex 9, La Réunion, France
}

\begin{abstract}
A B S T R A C T
A detailed magnetic mapping using Anisotropy of Magnetic Susceptibility (AMS) technique was carried out in Pointe Géologie archipelago (Terre Adélie, East Antarctica) that represents a hot crust having experienced a long-lived anatectic event during Paleoproterozoic times, $1.69 \mathrm{Ga}$ ago. AMS measurements allowed to better analyse the tectonic structure of the crystalline basement that is built up by rocks affected by various degrees of partial melting and then, devoid of clear strain markers. AMS sampling was performed from main rocks types of Pointe Géologie: migmatites including leucosomes and melanosomes, coarse-grained pink granites, anatexites and mylonitic gneisses. For melanosomes, the magnetic foliation is dominantly in agreement with the observed field foliation, i.e. dominantly $\mathrm{N}-\mathrm{S}$ sub-vertical in shear zones and gently inclined in dome structures. AMS technique reveals a sub-horizontal magnetic lineation in migmatites from shear zones and a gently plunging one in dome structures. Magnetic properties of leucosomes and of coarse-pink granitic dykes contrast with melanosomes. The bulk susceptibility and anisotropy degree are significantly lower in granitic magmas that in melanosomes. In addition, in well-defined leucosomes, granitic dykes and anatexites, the magnetic ellipsoid is characterized by a higher plunge of the magnetic lineation, which tends to be vertical. This is associated to a rheological contrast between the solid-state deformation suffered by oxide grains in the melanosomes and their reorientation in a viscous flow during the transfer of felsic melt to the granitic dykes. Magnetic structure of leucosomes, granitic dykes and anatexites highlights the role of the gravityinduced upwelling of a crust undergoing high degree of partial melting in a transpressional regime.
\end{abstract}

\section{Introduction}

Migmatites and anatexites result from progressive melting of rocks under high-grade metamorphism conditions (Wimmenauer and Bryhni, 2007 and references therein). These rocks are often the only key to determine the structural patterns in the deep crust. However, the structural analysis of migmatites is often not very easy because of their complex and multiphase evolution. Moreover, leucosomes and melanosomes produced by partial melting of an initially highly deformed rock acquire a fabric that mostly cannot be determined by classical structural approaches. In partially melted gneisses, i.e. migmatites, this fabric can differ from that of the initial parent rock. In dominantly melted rocks, the only visible fabric is mostly related to the orientation of rafts of melanosomes or mesosomes, i.e. respectively restites or protoliths, and therefore this fabric only offers an incomplete signature of the tectonic events suffered by the rocks during melting. Melanosomes and mesosomes usually

\footnotetext{
* Corresponding author. Tel.: + 33 477485124; fax: + 33477485108. E-mail address: jerome.bascou@univ-st-etienne.fr (J. Bascou).
}

exhibit features of metamorphic rocks whereas the leucosomes display an igneous-like appearance. Therefore, one of the characteristics of the migmatite structures is their local variability and then their analysis implies a large collection of data together with a statistical approach. To this aim, the field observations are limited to the few visible strain markers and generally not well-adapted.

The anisotropy of magnetic susceptibility (AMS) technique (see Borradaile and Henry, 1997; Borradaile and Jackson, 2004; Graham, 1954; Tarling and Hrouda, 1993 and references therein) has been widely used for structural applications. It offers several advantages relatively to field observations revealing not only foliation and lineation but also intensity and shape of the fabric and it can be applied to a set of samples representative of a significant area. Ferré et al. (2003), Kruckenberg et al. (2010) and more recently Viegas et al. (2013) used the magnetic anisotropy for migmatite study. They showed that despite rheological variations during deformation (solid-state deformation followed by viscous flow), AMS axes were consistent with observed regional field structures and thus highlighting the interest of the AMS data for the strain analysis in hightemperature metamorphic rocks. In paramagnetic migmatites, for which biotite is the main carrier of the magnetic susceptibility, the 
degree and the shape of the AMS ellipsoid could be different in granites and diatexites, and in metatexites (Hasalovà et al., 2008). Others authors have shown that anatexites could have specific AMS signature, associated with rheological properties and that AMS characterizations could therefore help to better model the different stages of migmatitic terrains (Charles et al., 2009; Kratinová et al., 2012; Schulmann et al., 2009).

The Pointe Géologie archipelago (Terre Adélie, East Antarctica) represents a mid-crustal section that experienced a long-lived anatectic event during Paleoproterozoic times, 1.69 Ga ago (Ménot et al., 2007 and references therein). This archipelago is partially covered by the ice cap and limited outcrops are key zones to constrain the Terre Adélie Craton tectonics. Pelletier et al. (2002) and Gapais et al. (2008) proposed a detailed structural and kinematic analyses of the area based on foliation and lineation measurements of migmatites. But we believe these structural data can be supplemented by taking into account the magnetic fabric of the leucosomes and anatexites, which correspond to more than $50 \%$ of the outcrops and which are devoid of clear strain markers. This would greatly improve the knowledge of the structural pattern of this region.

The first aim of this paper is thus to specify the deformation framework associated to the Paleoproterozoic event in the Terre Adélie Craton from a large sampling in the Pointe Géologie rocks. For this, a detailed AMS study was performed in the migmatites, the larger granitic dykes and the anatexites observed in the field. Finally, we focus on various migmatitic structures of centimetric to decametric size; they correspond to various phases of segregation, extraction and transfer of melts. We discuss the relationships between these different migmatitic habitus and their related AMS signature in order to constrain the rheological evolution of the molten crust.

\section{Geological setting}

The Terre Adélie Craton (TAC) is located in the easternmost part of the East Antarctic Shield. It crops out as islands and capes scattered along the coast between $135^{\circ}$ and $145^{\circ} \mathrm{E}$ but most of the outcrops are located in three main archipelagos, from West to East: around Pointe Géologie $\left(66^{\circ} 40^{\prime} \mathrm{S}, 140^{\circ} \mathrm{E}\right)$, East of Port Martin $\left(66^{\circ} 49^{\prime} \mathrm{S}, 141^{\circ} 24^{\prime} \mathrm{E}\right)$ and East of Cape Denison $\left(67^{\circ} 00^{\prime} \mathrm{S}, 142^{\circ} 40^{\prime} \mathrm{E}\right)$ up to the Mertz glacier. This crystalline basement consists of Late Archean and Paleoproterozoic formations devoid of any significant reworking since $1.5 \mathrm{Ga}$ and then it is considered as part of the Mawson block or Mawson continent (Fanning et al., 1995, 2002). At the scale of the TAC (Fig. 1a), the Late Archean and Paleoproterozoic terrains are distributed westwards and eastwards from Port Martin, respectively (Ménot et al., 2007; Monnier et al., 1996).

This paper deals only with the Paleoproterozoic formations of the Pointe Géologie area, i.e. around the permanent French Polar Station Dumont d'Urville (DDU). As described by Bellair (1961a,b), the main rock types are migmatitic to anatectic gneisses that are cross cut by dykes of apparently isotropic coarse-grained pink granites. The detailed mapping, carried on during the GEOLETA project, improves this previous description and points out some new and significant features (Gapais et al., 2008; Monnier et al., 1996; Peucat et al., 1999). Migmatitic gneisses and anatexites derived from a sedimentary sequence dominated by aluminous pelites together with subordinate greywackes, quartzites and calc-silicates. Metagreywakes appear as intercalations ranging from tens of centimetres to hundreds of metres in thickness. Quartzites and calc-silicates form dismembered layers and enclaves of mesosomes within the migmatites and they mark out a poorly preserved sedimentary layering (Fig. 2a). Amphibolitized dolerites and gabbros occur as dykes and sills and they are coeval with the anatectic event as shown by magma mingling features between the mafic intrusions and the granitic magmas. Isotopic data indicate Paleoproterozoic sources for both sediments and magmas (Peucat et al., 1999 and references therein). According to Monnier et al. (1996), mesosomes, neosomes and anatexites represent respectively 10\%, 60\% and 30\% of the rock types in the Pointe Géologie archipelago.

These migmatites and anatectites formations underwent a polyphased tectonic and metamorphic evolution with three phases of deformation leading to a composite sub-vertical regional $\mathrm{S}_{0}-\mathrm{S}_{1}-\mathrm{S}_{2}$ foliation (Monnier et al., 1996; Pelletier et al., 2002, 2005). Neosomes display two successive parageneses related to both the $S_{1}$ and $S_{2}$ metamorphic foliations and bearing more or less comparable Sil $\pm \mathrm{Kfs} \pm \mathrm{Pl} \pm$ $\mathrm{Bt} \pm \mathrm{Cd} \pm \mathrm{Grt} \pm \mathrm{Ilm} \pm \mathrm{Qtz}$ mineral assemblages. The leucosomes are enriched in Qtz, Kfs and Pl and also contains Crd and Sil and subordinate Bt and Grt. Moreover, mineral chemistry of the $S_{1}$ and $S_{2}$ parageneses and of the successive generations of leucosomes is similar and argues for a single continuous Low Pressure-High Temperature metamorphic event, the peak conditions reaching $750-700{ }^{\circ} \mathrm{C}$ at $0.6-0.4 \mathrm{GPa}$. Large amounts of anatectic melts have been produced all along the tectonic and metamorphic evolution as suggested by the various habitus of the leucosomes and their chronology relative to the composite foliation $\mathrm{S}_{1}-\mathrm{S}_{2}$ (Fig. 2). The oldest leucosomes appear as mylonitic lenses isoclinally folded by the $S_{1}-S_{2}$ transposition, but most of them are undeformed and concordant within the $S_{2}$ foliation and the latest melts cross cut the $S_{2}$ planes. But all the successive generations display the same mineral assemblages and chemistry. A retrograde imprint with $\mathrm{Bt} \pm \mathrm{Ms} \pm$ And assemblages marks the later evolution to about $550-450{ }^{\circ} \mathrm{C}$ and $0.5-$ 0.4 GPa (Gapais et al., 2008; Monnier et al., 1996; Pelletier et al., 2002).

According to Pelletier et al. (2002) and Gapais et al. (2008), the Pointe Géologie archipelago shows two types of structural domains: $\mathrm{N}-\mathrm{S}$ to $\mathrm{N} 340^{\circ}$ striking vertical shear zones and domes, both of them developed during the metamorphic and anatectic event (Fig. 1b). Between the vertical zones, the foliation attitudes point out dome-shaped structures marked by flat lying to gently plunging fabrics. Domes display a mineral lineation outlined by a preferred orientation of sillimanite crystals while such a lineation is almost invisible in the vertical zones. The transition from flat lying to vertical foliation zones can be sharp, with development of vertical foliation planes cutting across the horizontal foliation of domes. It can also correspond to gradual folds with horizontal axes. Such a transition from dome to vertical shear zone never exceeds $500 \mathrm{~m}$ in thickness. Frequently, the vertical structures seem to be younger than the flat-lying ones but flat-lying structures reworking vertical ones have also been observed. Moreover, all these structures were developed under similar Pressure-Temperature and syn-anatectic conditions and then can be considered as nearly coeval (Monnier, 1995; Pelletier et al., 2002). Such patterns could be explained in the frame of a regional convergence, toward a cool rigid Archean craton, of a hot and weak juvenile crust leading to horizontal crustal flow and strain partitioning with localized deformation along transpressional shear zones.

Bellair and Delbos (1962) assumed a 1.5 Ga age (Rb/Sr on micas) for the partial melting event. More recently, new radiometric data (Peucat et al., 1999, U-Pb on zircons and monazites, Sm-Nd and $\mathrm{Rb}-\mathrm{Sr}$ on whole rocks and minerals) gave precise time constraints on the geological evolution of the meta-volcano-sedimentary formations of Pointe Géologie. Time of sediments deposition is bracketed between the inherited zircon ages $(1.76-1.72 \mathrm{Ga})$ and the peak of metamorphism and partial melting occurred at $1.69 \mathrm{Ga}$. The later cooling path was constrained by $\mathrm{Nd}$ garnet ages $\left(650-600{ }^{\circ} \mathrm{C}\right.$ at $1.63-1.60 \mathrm{Ga})$ and $\mathrm{Rb}-\mathrm{Sr}$ muscovite and biotite ages $\left(450-350{ }^{\circ} \mathrm{C}\right.$ at $1.5 \mathrm{Ga})$.

\section{High temperature rock types and regional structures}

While the lithology is very homogeneous in the scale of the archipelago, field relationships between different rock types are much more complex in the outcrops scale. Four main rock types have been sampled for AMS measurements: migmatites including leucosomes and melanosomes, coarse-grained pink granites, anatexites and strongly mylonitic gneisses. 

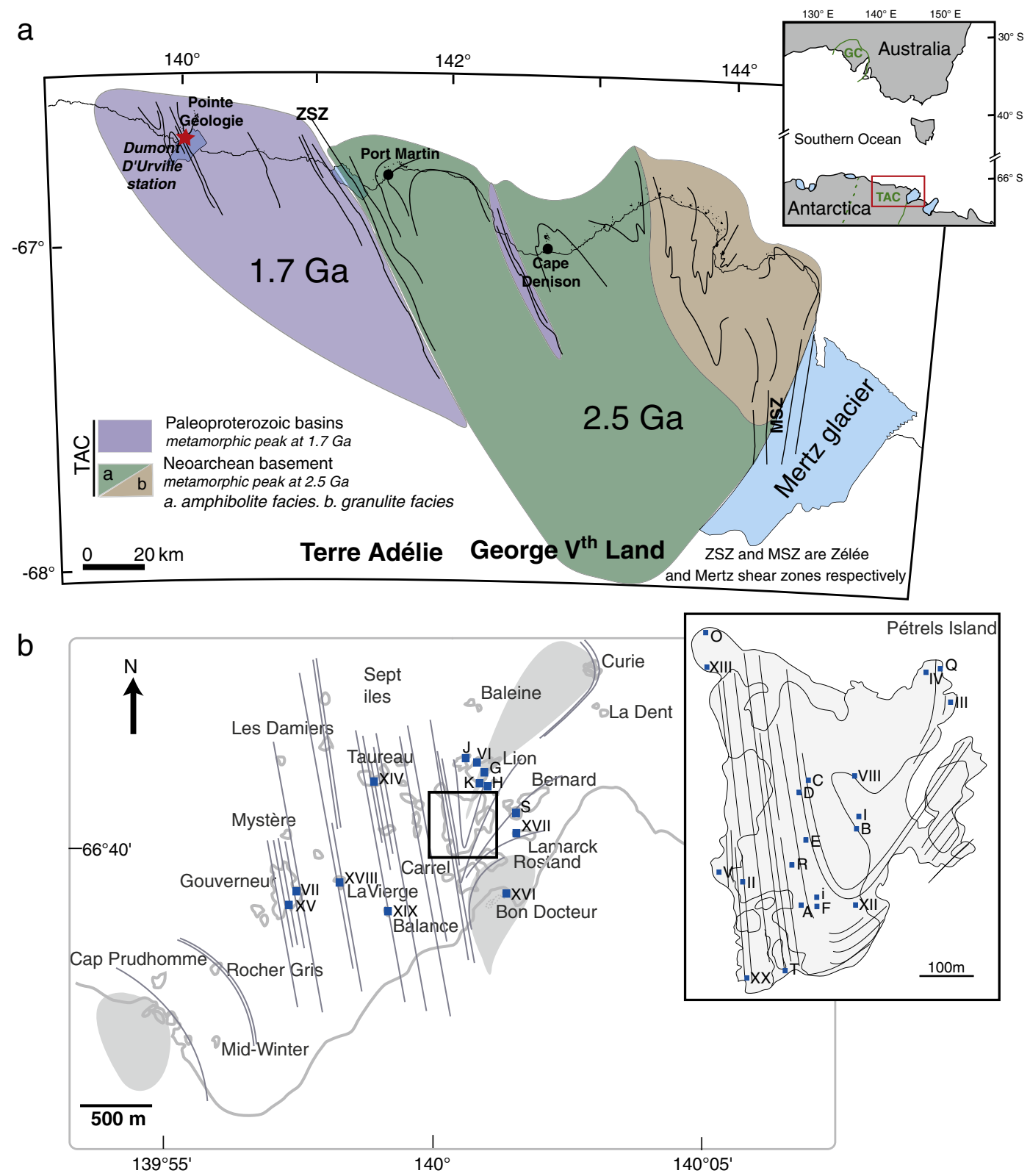

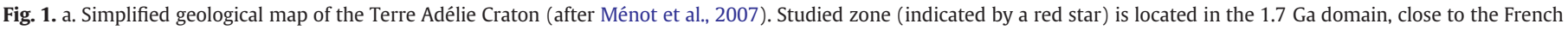

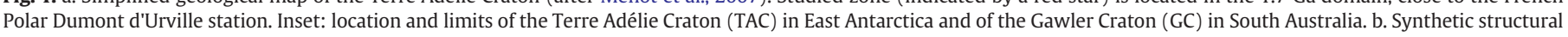
map of the Pointe Géologie archipelago and location of AMS sites.

\subsection{Migmatitic gneisses}

They have been described previously as the K-feldspar gneisses (Monnier et al., 1996; Pelletier et al., 2005) and they are the dominant facies, especially on the Pétrels Island (Dumont d'Urville station, Fig. 1). We will discuss more specifically the space and time relationships between leucosomes and melanosomes in the migmatitic gneisses. As partial melting developed all along a polyphased tectonic and metamorphic event, leucosomes display various habitus relative to the composite foliation $S_{1}-S_{2}$, which is marked on the field by more or less continuous layers for melanosomes and septas of mesosomes (Fig. 2a):

(i) The earliest leucosomes occur as elongated and mylonitized lenses, sometimes affected by synfolial folds leading to the $S_{2}$ foliation. They bear evidence of successive segregation and deformation processes, syn $S_{1}$-ante $S_{2}$ and syn $S_{2}$, respectively (Fig. 2a).

(ii) The most common leucosomes are undeformed and concordant within the migmatites foliation, possibly affected later by post-foliation open folds. They represent syn- to late- $S_{1}-S_{2}$ foliation melts (Fig. 2b).

(iii) The latest leucosomes form dykelets crosscutting, and postdating, the $S_{1}-S_{2}$ foliation. They can be connected to the concordant leucosomes, tapping off and transferring melts upwards (Fig. 2a, c).

\subsection{Coarse-grained pink granites}

They appear as dykes of decimetric to decametric thickness that cross cut the regional foliation (Fig. 2d). They are devoid of any visible 

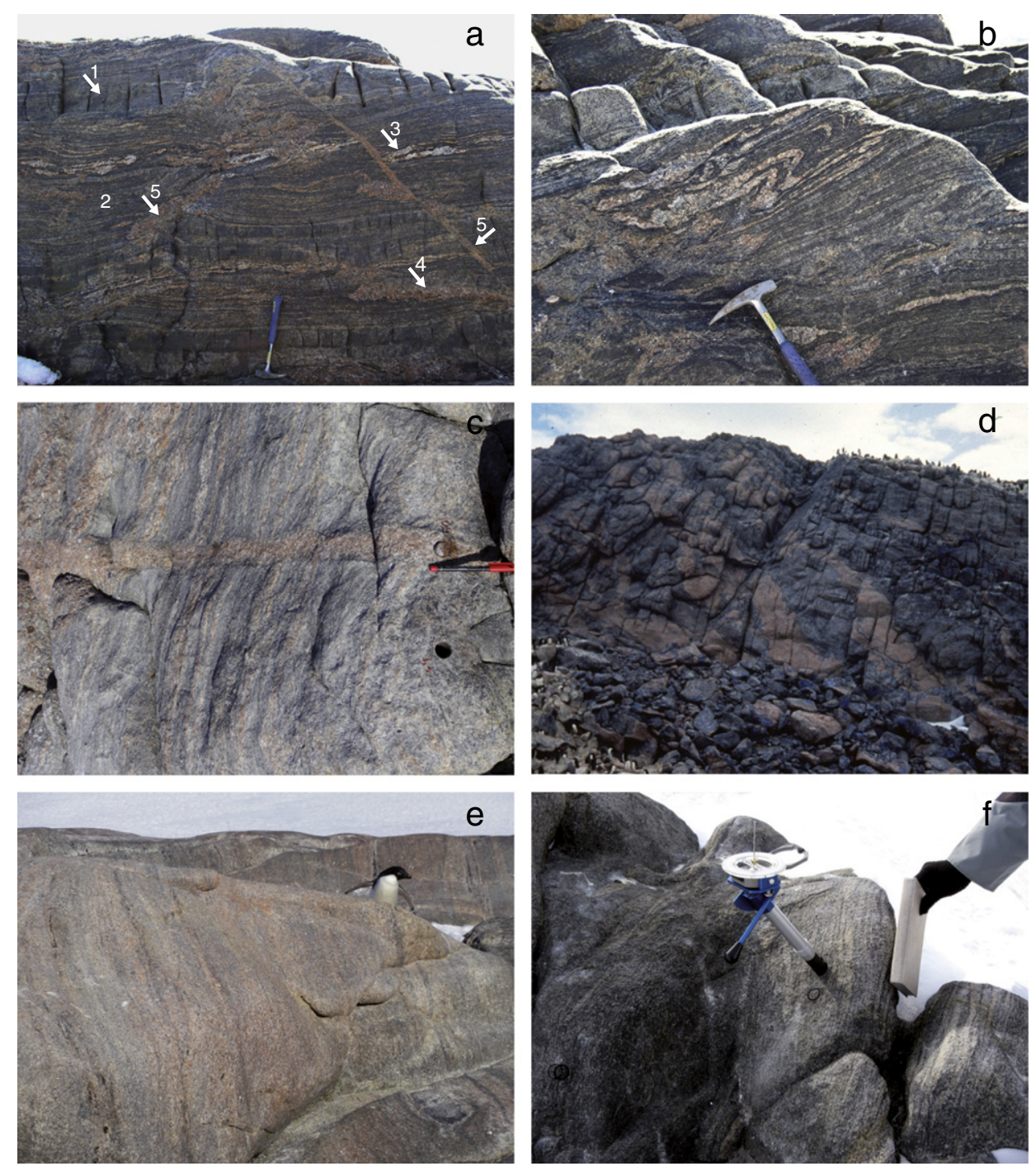

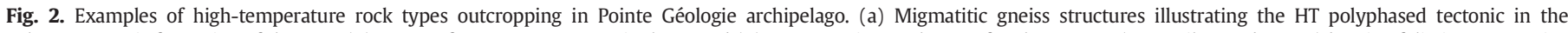

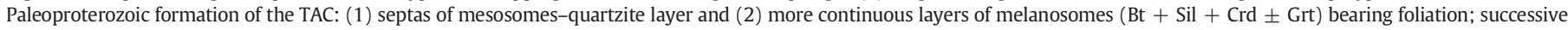

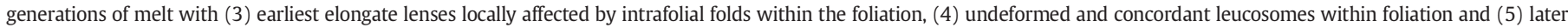

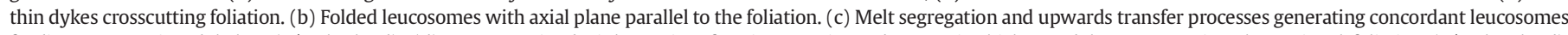

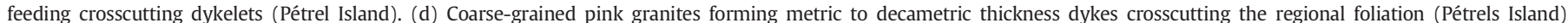

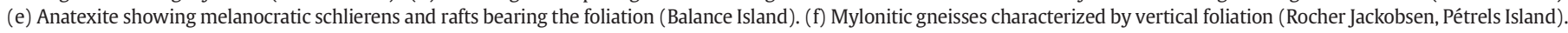
The solar compass used to determine the geographical orientations of tectonic structures gives the photograph scale.

markers of orientation. Such dykes, collecting the dykelets, drain the more evolved melts during the late- to post-tectonic stages of the partial melting and metamorphic event.

\subsection{Anatexites}

They outcrop widely on the western area of Pointe Géologie (e.g., Gouverneur, Balance, Taureau and La Vierge Islands, Fig. 1b). They derived from a higher degree of partial melting than migmatitic gneisses and show a mineral assemblage comparable to that of leucosomes but more enriched in Qtz and depleted in Crd. Anatexites display more isotropic textures but a flow fabric or a palimpsest structure of the parent gneisses is often marked by some oriented rafts of migmatitic gneisses or schlierens of biotite and oxides (Fig. 2e).

\subsection{Mylonitic gneisses}

They crop-out in a restricted and narrow zone on the western flank of the Pétrels Island (Rocher Jakobsen) and some islands of
Pointe Géologie, i.e. along a major $\mathrm{N}-\mathrm{S}$ to $\mathrm{N} 340^{\circ}$ striking vertical shear zone (sites II and V, Fig. 1b). They consist of Bt + Grt gneisses with only tiny Grt-bearing leucosomes and are characterized by a vertical mylonitic foliation. They derive from the K-feldspar migmatitic gneisses and then may be considered as late- to post-migmatisation tectonites (Fig. 2f).

\section{Sampling and methodological procedures}

Because of outcrops restriction (areas non accessible because of ice cover or of birds protection) and high variability of the visible deformation, sampling was often made in sites relatively close one to another in the main island (Pétrels Island). Other sites were scattered in different smaller islands (Fig. 1b). Most sampled sites correspond to a surface up to $50 \mathrm{~m}^{2}$.

For the magnetic fabric study, cores were sampled with a gasolinepowered portable drill. All the cores were oriented only with a sun compass (Fig. 2f) because of the immediate proximity of the south magnetic pole. This introduced a strong limitation for sampling 
because of climatic conditions. The sampling was made during three different summer fieldworks, in 1992, 2009 and 2011. As a whole, 819 rock cores were obtained in 33 sites, including 20 on the Pétrels Island (Fig. 1b). When possible, different facies (from gneiss to anatexites) were sampled on the same site. The cores were cut in the laboratory in specimen of standard paleomagnetic size.

Magnetic susceptibility and its anisotropy have been measured using Kappabridges KLY3 and MKF1 (AGICO, Brno). The determined AMS ellipsoid yields the three principal susceptibility axes defined as $K_{1} \geq K_{2} \geq K_{3}$. $K_{1}$ is the magnetic lineation and $K_{3}$ is perpendicular to the magnetic foliation and the bulk magnetic susceptibility is $\mathrm{Km}=\left(\mathrm{K}_{1}+\mathrm{K}_{2}+\mathrm{K}_{3}\right) / 3$. The Jelínek (1981) parameters $\mathrm{P}^{\prime}$ and $\mathrm{T}$ were used to describe the intensity and the shape of the magnetic fabric, respectively. Data for a group of samples were analysed using normalized tensor variability (Hext, 1963; Jelínek, 1978) statistics.

Thermomagnetic experiments were performed on representative samples by heating in argon or in air using the CSL equipment and the CS2-3 oven (AGICO, Brno) associated with the Kappabridges. Hysteresis loops were obtained for small cores (cylindrical samples of about $3 \mathrm{~cm}^{3}$ ) using a laboratory-made translation inductometer within an electromagnet capable of reaching 1.6 T.

\section{Magnetic mineralogy}

\subsection{Thin sections study}

As the magnetic characteristics of the rocks are tightly controlled by their mineralogical content, the various assemblages recorded in the different rock types need to be specified. This is particularly important for migmatitic gneisses where partial melting induces a redistribution of refractory minerals from the mesosomes to both the melanosomes and leucosomes.

Magnetite and ilmenite are the most abundant oxide minerals. They form discrete grains or clusters with direct contact between magnetite and ilmenite. The larger grains (millimetric in size) are generally found in the melanosomes and therefore in the foliation and they appear as elongated parallel to the lineation defined by the sillimanite when the latter is present (Fig. 3). In addition to the observed lengthening of magnetite and ilmenite grains parallel to this lineation, measurement of lattice preferred orientations (LPO) of

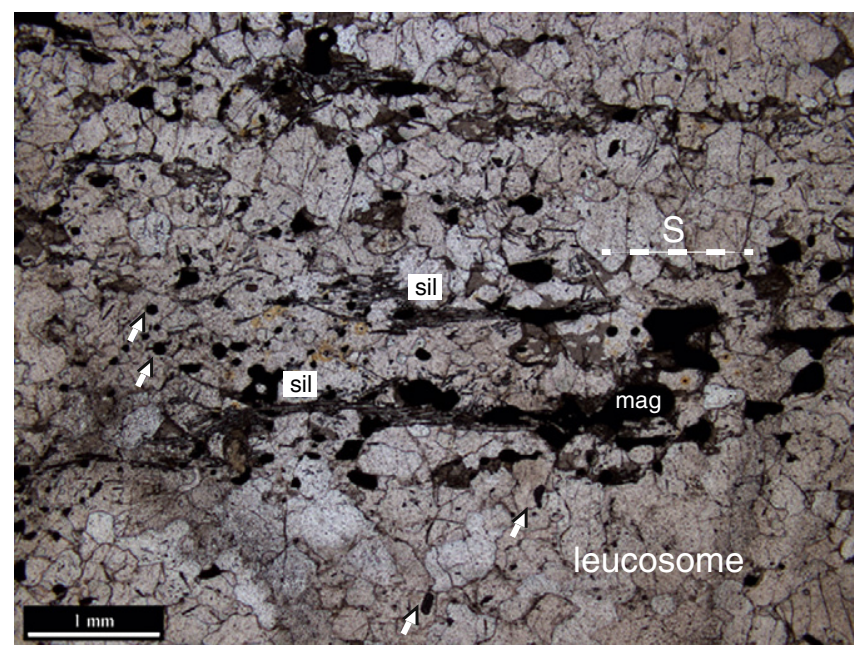

Fig. 3. Photomicrograph of migmatitic gneiss in the vertical shear zone (Lamarck Island), perpendicular to the foliation $(S)$ and parallel to the lineation. Sillimanite (sil) and elongated oxide grains (mainly magnetite (mag) in this sample) are parallel to the lineation in the melanocratic layers. The shape of oxide grains tends to be more rounded perpendicular to the lineation and parallel to the foliation in more leucocratic areas (see white arrows). these minerals by indexation of electron back-scattered diffraction (EBSD) patterns (e.g., Bascou et al., 2002; Prior et al., 1999) shows that for ilmenite, deformation also induces LPO-related structural axes (measurements performed using a SEM-JSM 5600 at the University of Montpellier - France). Pole figure projections (Mainprice's software, Geosciences Montpellier) of ilmenite crystallographic planes from gneisses of the vertical shear zones show relatively strong LPO which is characterized by poles of (0001) planes strongly concentrated close to the normal to the foliation, and by the poles of (2-1-10) and (10-10) prism planes concentrated close to the lineation (Fig. 4). Oxides are also present in the leucosomes but the fabric (grains alignment) appears to be more scattered than in the melanosomes. At the melanosome-leucosome boundary, elongated grains, maybe rotated, have been observed with high angle to the foliation. In the leucosomes, the oxide grains become more discrete and more rounded perpendicular to the lineation (and parallel to the foliation for samples from vertical shear zones; Fig. 3).

Cordierite is also present in migmatitic gneisses and granitic dykes of Pointe Géologie. This mineral that occurs mainly as grains of globular shape (up to a few millimetres in size) is carefully considered because cordierite presents specific magnetic properties. It carries an inverse magnetic fabric (i.e. characterized by a switch between the principal maximum $\mathrm{K}_{1}$ and minimum $\mathrm{K}_{3}$ axes of the AMS ellipsoid with respect to the grain shape; Potter and Stephenson, 1988; Rochette et al., 1992) that could lead to misinterpretation of the measured magnetic fabrics. However, the mean magnetic susceptibility $(\mathrm{Km})$ for magnetite, which is ubiquitous in studied thin sections, is significantly higher than for cordierite (Km ratio $>1000)$. Therefore magnetite should be the main carrier of measured AMS. For relatively large grains of magnetite, the $\mathrm{K}_{1}$ and $\mathrm{K}_{3}$ axes correspond to the magnetic lineation and magnetic foliation poles, respectively.

\subsection{Rock-magnetism}

The mean magnetic susceptibility Km (average $5.2 \cdot 10^{-2} \mathrm{SI}$ ) of the studied samples is different according to the studied fraction of the migmatites (Fig. 5). The gneisses with subordinate melted component and dominant melanosome fraction have very high susceptibility (average $7.4 \cdot 10^{-2} \mathrm{SI}$ ). Km values for dominant granitic fraction are lower (average $1.5 \cdot 10^{-2} \mathrm{SI}$ ). Migmatite samples including both leucosome and melanosome fractions present intermediate $\mathrm{Km}$ values. This variability in leucosome versus melanosome content of gneissic specimens largely explains the relatively large distribution of susceptibilities (Fig. 5). The anatexite samples show the highest variation in Km values.

All thermomagnetic KT curves (susceptibility $\mathrm{K}$ as a function of temperature T) show a sharp susceptibility decrease around $580{ }^{\circ} \mathrm{C}$ during heating (Fig. 6), clearly indicating the presence of magnetite. In addition low temperature experiments confirm the presence of this mineral by a large susceptibility increase around $-160{ }^{\circ} \mathrm{C}$ (Fig. 6). This variation corresponds to the Verwey transition that is characteristic of pure magnetite. Few thermomagnetic curves are perfectly reversible. Susceptibility values from the cooling curve are slightly higher than the initial values, in air as in argon atmosphere (but sometimes much higher as for the sample AP35). Partial cooling loops during heating evidenced a weak mineral alteration due to heating around 300 to $400{ }^{\circ} \mathrm{C}$ that probably reflects transformation of a weak amount of maghemite in hematite. New magnetite is also often formed at the highest temperatures.

Hysteresis loops show generally a full saturation of the magnetization for moderate field (Fig. 7). This saturation was partial only for the sample AP35, evidencing the presence of another component of high coercivity. This component is probably hematite. In most cases, ferrimagnetic minerals have a largely dominant effect for the susceptibility, but two of the studied granite samples highlight also a strong contribution of the paramagnetic or even diamagnetic minerals. Day 
(2i10)

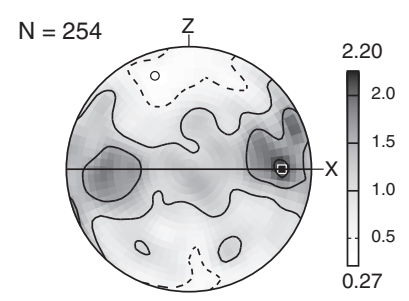

(1010)

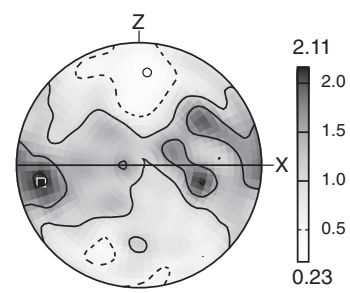

(0001)

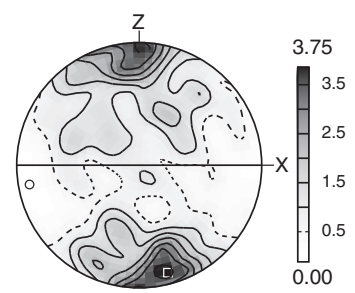

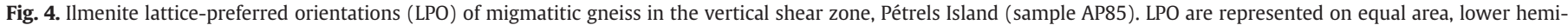

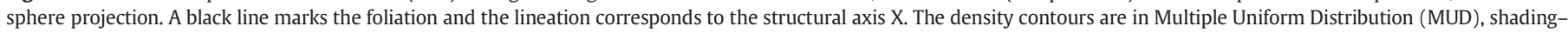
inverse log; $\mathrm{N}$ is the number of measured grains.

plot (Day et al., 1977) for mainly magnetite-bearing samples clearly evidences a large size of the magnetite particles (Fig. 8).

Main magnetic mineral is therefore magnetite with a large grain size. Obtained AMS data are then directly usable for a structural analysis (no inverse magnetic fabric due to small Single Domain particles Potter and Stephenson, 1988).

\section{Magnetic fabric}

\subsection{Structures from AMS}

Data for migmatitic gneisses and for granites are presented separately (for migmatitic gneissic including minor melted parts and "granitic" samples small amounts of melanosome assemblage this separation has been made then considering the dominant presence of one of these components). Moreover, from the regional structural field pattern, two distinct zones have been distinguished for the AMS analyse: the sub-vertical zones and the dome-shaped zones (Figs. 9 and 10). Maps of the AMS foliations and lineation are presented in Fig. 11.

\subsubsection{Structures in sub-vertical domains}

In migmatitic gneisses from sub-vertical shear zones ( sites A, D, O, R, T, and XIII of Pétrels Island - Fig. 10), melanosome layers show generally both well clustered magnetic foliation pole $\left(\mathrm{K}_{3}\right)$ and magnetic lineation $\left(\mathrm{K}_{1}\right)$. The magnetic foliation is dominantly sub-vertical $\mathrm{N}-\mathrm{S}$ consistent with the observed field foliation, and the magnetic lineation presents a weak plunge and $\mathrm{N}-\mathrm{S}$ trend. The granitic rich layers (site XIII $\gamma$ ) display more diffuse fabric, in particular the $K_{1}$ axes that tend to form a girdle perpendicular to $\mathrm{K}_{3}$. Well-individualized leucosomes (e.g. Fig. 2C) show a different magnetic fabric signature than

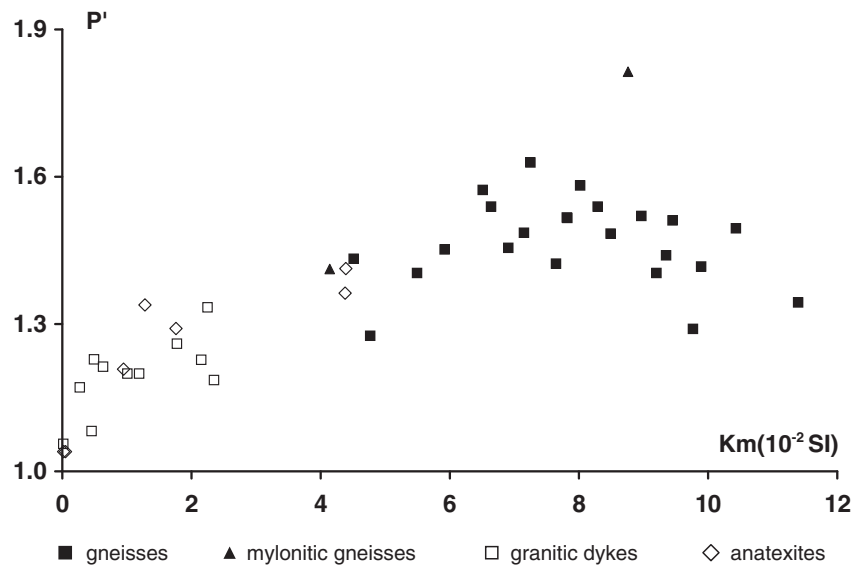

Fig. 5. $\mathrm{P}^{\prime}$ parameter as a function of $\mathrm{Km}$ values for high temperature main rock types of the Pointe Géologie archipelago. melanosome layers characterized by strongly inclined to sub-vertical magnetic lineation (site XIII $\gamma$ - Fig. 10). The $\mathrm{K}_{3}$ axes are more scattered than the $K_{1}$ axes. They are in the horizontal plane with two dominant directions: N-S and E-W.

In large coarse-grained pink granite dykes (sites A $\gamma, \mathrm{D} \gamma, \mathrm{E} \gamma-$ Fig. 10) the $K_{3}$ axes are relatively well clustered defining a subvertical magnetic foliation of strike close to that of neighbouring gneisses (sites D $\gamma, \mathrm{E} \gamma$ ) or showing a divergent strike (sites A $\gamma$ ). The magnetic lineation pattern is characterized by the verticalization of $\mathrm{K}_{1}$ axes in comparison to magnetic lineation measured in the melanosome layers of neighbouring gneisses. They form girdle perpendicular to $K_{3}$ (site E $\gamma$ ) or strongly inclined to sub-vertical local maximum (sites D $\gamma$ and $A \gamma$, respectively).

In anatexites of Gouverneur, Taureau, La Vierge, Balance Islands (sites VII $\gamma, \mathrm{XV} \gamma, \mathrm{XIV} \gamma, \mathrm{XVIII} \gamma, \mathrm{XIX} \gamma-$ Fig. 9) and South of Pétrels Island (site XX $\gamma-$ Fig. 10) $K_{1}$ tends to have high inclination or to be sub-vertical. For Gouverneur anatexites (sites VII $\gamma, \mathrm{XV} \gamma$ ) the clustering of $K_{1}$ is strong. $K_{3}$ lies in the horizontal plane, relatively scatted or forms clusters at $90^{\circ}$ from each other with the N-S and E-W directions that prevails for south Gouverneur Islands (site XV $\gamma$ ). Sampling sites XIV $\gamma$ and XVIII $\gamma$ (Fig. 9) show heterogeneities in the partial melting degree that is expressed in the field by the frequent occurrence of migmatitic gneiss rafts in the anatexites. For site XVIII $\gamma$ (La Vierge Island) anatexites and migmatitic gneisses show distinct magnetic axes orientations characterized by $K_{1}$ preferentially sub-vertical and $\mathrm{K}_{3}$ horizontal $\mathrm{N}-\mathrm{S}$ (i.e., magnetic foliation vertical $\mathrm{E}-\mathrm{W}$ ) in anatexites while $K_{1}$ is horizontal to strongly plunging $N-S$ and $K_{3}$ is horizontal E-W (i.e., magnetic foliation vertical $\mathrm{N}-\mathrm{S}$ ) in neighbouring gneisses. The $\mathrm{N}-\mathrm{S}$ orientation of magnetic foliation in gneisses fit quite well with the regional vertical shear zone structures. In opposite, the E-W vertical magnetic foliation that appears in the larger dykes and anatexites is less well-constrained by large-scale field structures (Fig. 9). For site XIVY (Taureau Island) the distinction in the field between the anatexites and the migmatitic gneisses was difficult to make, explaining the relatively wide confidence zones at $95 \%$ for $K_{1}$ and $K_{3}$. However the magnetic fabric is mainly oriented vertical E-W for the foliation and strongly-inclined (westward) for the lineation.

In mylonitic gneisses of Rocher Jakobsen (sites II, V - Fig. 10) the magnetic foliation $\left(\mathrm{K}_{1}-\mathrm{K}_{2}\right)$ is dominantly sub-vertical N-S consistent with the observed field structures (Fig. 2f). In contrast, the AMS measurement reveals uncommon strongly plunging to sub-vertical lineations.

\subsubsection{Structures in dome-shaped zones}

In the migmatitic gneisses of the dome-shaped zones (sites $\mathrm{G}, \mathrm{H}, \mathrm{J}$, K, S, VI, XVI, XVII - Fig. 9; sites B, C, F, i, Q, I, III, IV, VIII, XII - Fig. 10) magnetic fabric displays a stronger variability of $K_{1}$ and $K_{3}$ axes orientations from one site to another one in comparison to structured vertical shear zones. A relatively strong dip (about $45^{\circ}$ ) for the magnetic foliation is frequently observed, in particular for the sites located in 


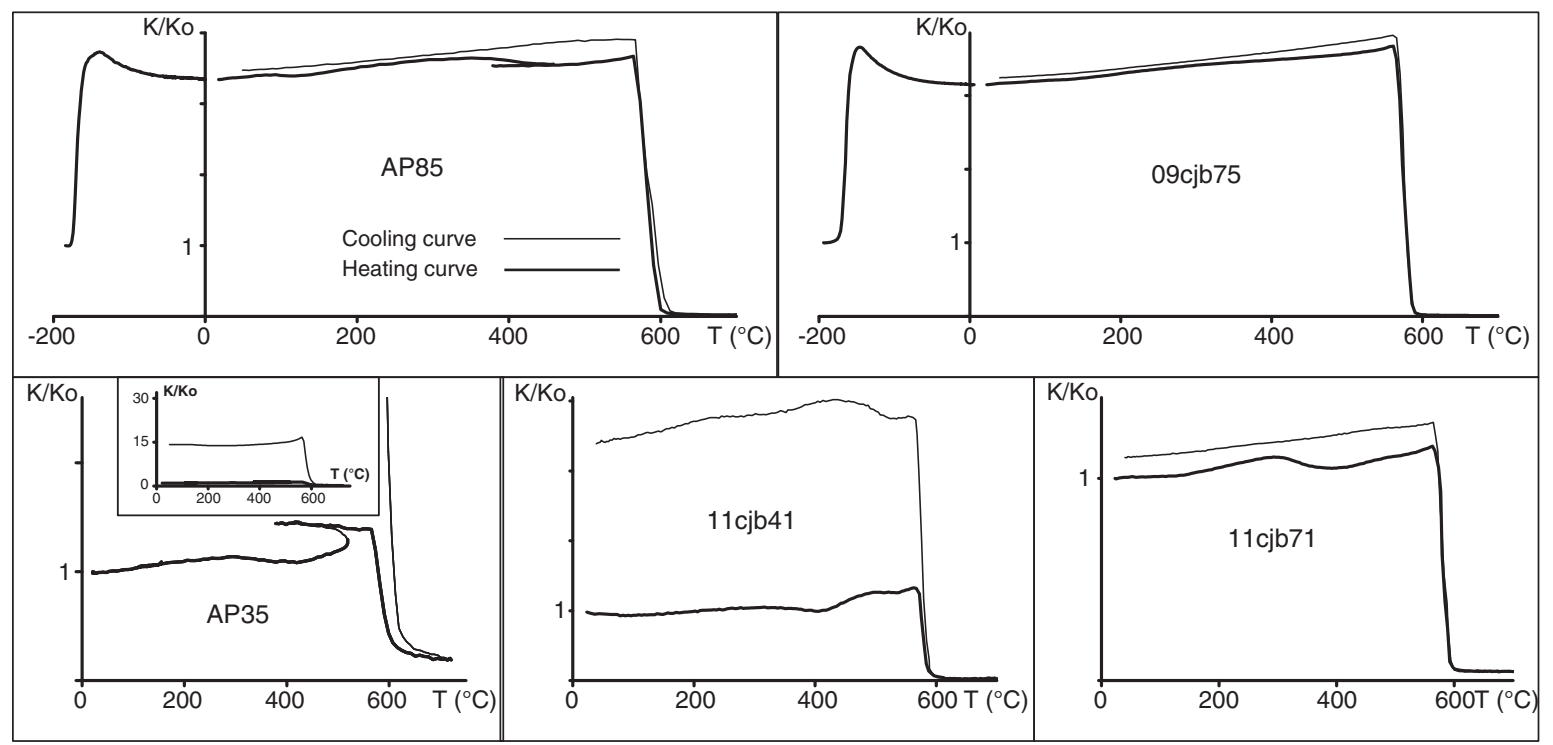

Fig. 6. Normalized susceptibility K/Ko as a function of the temperature T in gneisses (samples AP35 and AP85) and in granites (09cjb75, 11cjb41 and 11cjb71).

the flanks of domes (sites H, K - Fig. 9; sites Q, III, IV - Fig. 10) for the eastern flanks of the Pétrels-Curie Islands dome. The magnetic foliations are generally in agreement with the field measured strikes and dip of melanosome layers. The magnetic lineations show gently plunge and dominant NNW strike. The innermost zones of domes (sites XVI, XVII - Fig. 9; sites B, I, VIII - Fig. 10) show also a strong variability of AMS structure patterns correlated to the complexity of migmatitic structures observed at the domes apex. In these areas are observed the less well-defined magnetic directions (with the widest confidence zones at 95\%: site XVI - Fig. 9; site I - Fig. 10). Sampling in a granitic dykelet of centimetric width crosscutting flat-lying gneissic foliation was performed in site XVII $\gamma$ (Fig. 9). The related AMS pattern is characterized by vertical N-S magnetic foliation and sub-vertical magnetic lineation and then differs from that of gneisses.

Large dykes of coarse-grained pink granites sampled in sites F $\gamma$ and XII $\gamma$ (Fig. 10) are characterized by vertical magnetic lineation, which contrasts with the magnetic lineation in the melanosomes of gneisses. This feature is similar to that observed in the granitic bodies from the sub-vertical shear zones. The magnetic foliation in the granitic dykes is either concordant with that of host gneisses (site F $\gamma$ ) or discordant (site XII $\gamma$ ).

\subsection{AMS parameters $\left(P^{\prime}\right.$ and $\left.T\right)$}

Fig. 12 presents the characteristics of the susceptibility ellipsoid. The degree of anisotropy $\mathrm{P}^{\prime}$ is very high in migmatitic gneisses (mean 1.48; minimum 1.04; maximum 1.90). It is lower in granites (mean 1.22; minimum 1.04; maximum 1.41). The shape of the susceptibility ellipsoid is dominantly oblate, in gneisses (for T value: mean 0.30 ; minimum -0.08 ; maximum 0.66 ) as in granites (mean 0.25 ; minimum -0.10 ; maximum 0.62). In granites, a clear relationship (Fig. $5, \mathrm{R}^{2}=0.70$ ) between $\mathrm{P}^{\prime}$ (intensity of the fabric) and $\mathrm{Km}$ (related

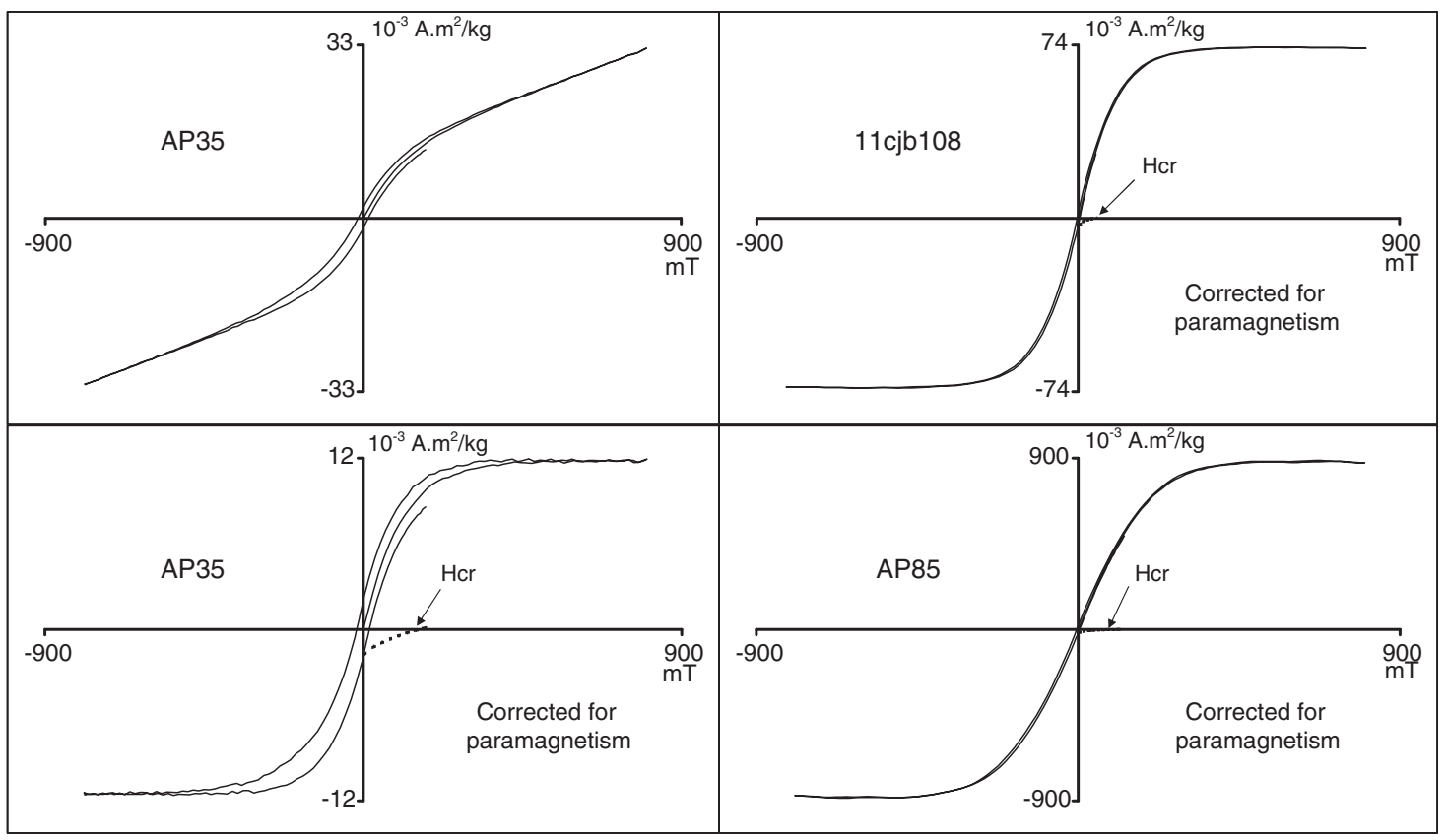

Fig. 7. Hysteresis loops for gneisses (AP35 and AP85) and granite (11cjb108). Hcr: Remanent coercive force. 


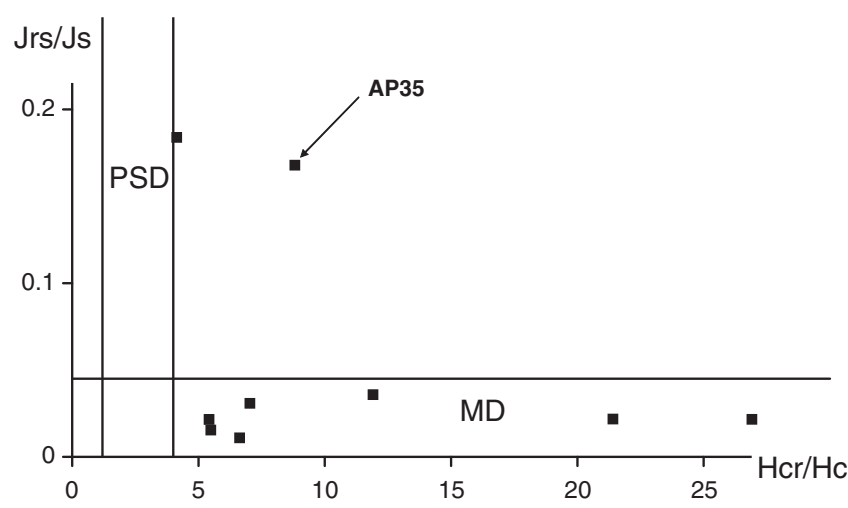

Fig. 8. Ratios of hysteresis parameters (Day et al., 1977): Jrs/Js (Jrs: remanence at saturation; Js: magnetization at saturation) as a function of $\mathrm{Hcr} / \mathrm{Hc}$ ( $\mathrm{Hcr}$ : remanent coercive force; Hc: coercive force). Areas for Multi-Domain (MD) and Pseudo Single Domain (PSD) grain size for pure magnetite.

to the concentration in ferrimagnetic minerals) highlights the dominant effect of the magnetite in the AMS (Henry et al., 2004). In addition, for granite, the anatexites show the highest variability in $\mathrm{P}^{\prime}$ and $\mathrm{T}$ values, including the extreme values (Fig. 12).

\section{Discussion}

\subsection{Mean susceptibility $(\mathrm{Km})$ and anisotropy $\left(\mathrm{P}^{\prime}\right)$ signature}

The amount of magnetite is clearly different in migmatitic gneisses and in granites (leucosomes and dykes), as shown by the susceptibility values (Fig. 5). This variation of magnetic susceptibility between melanocratic and leucocratic layers is mainly due to the variations in magnetite content. Magnetic studies suggest also mineralogical changes affecting magnetite with formation of ferromagnetic oxides of lower susceptibility like maghemite or hematite. Concerning this mineralogical change, gneiss sample AP35 (close to site R, Fig. 1) is the only one with hematite; it also presents the strongest formation of a lot of new magnetite at high temperature (susceptibility becomes 14 times higher on the cooling KT curve). It is therefore probably due to a strong local mineralogical alteration (interaction with deep fluids, weathering?) and remains an exception. In addition, in site test $\mathrm{R}$, magnetic and field structures (foliations and lineations) show a good agreement (Figs. 10 and 11), indicating that the primary AMS signature is relatively unaffected by such secondary mineralogical alteration.

The intensity of magnetic anisotropy, illustrated by the $\mathrm{P}^{\prime}$ values, is lower in granites than in gneisses (Fig. 12). In granites, it presents a relationship with the $\mathrm{Km}$ values, suggesting that this difference

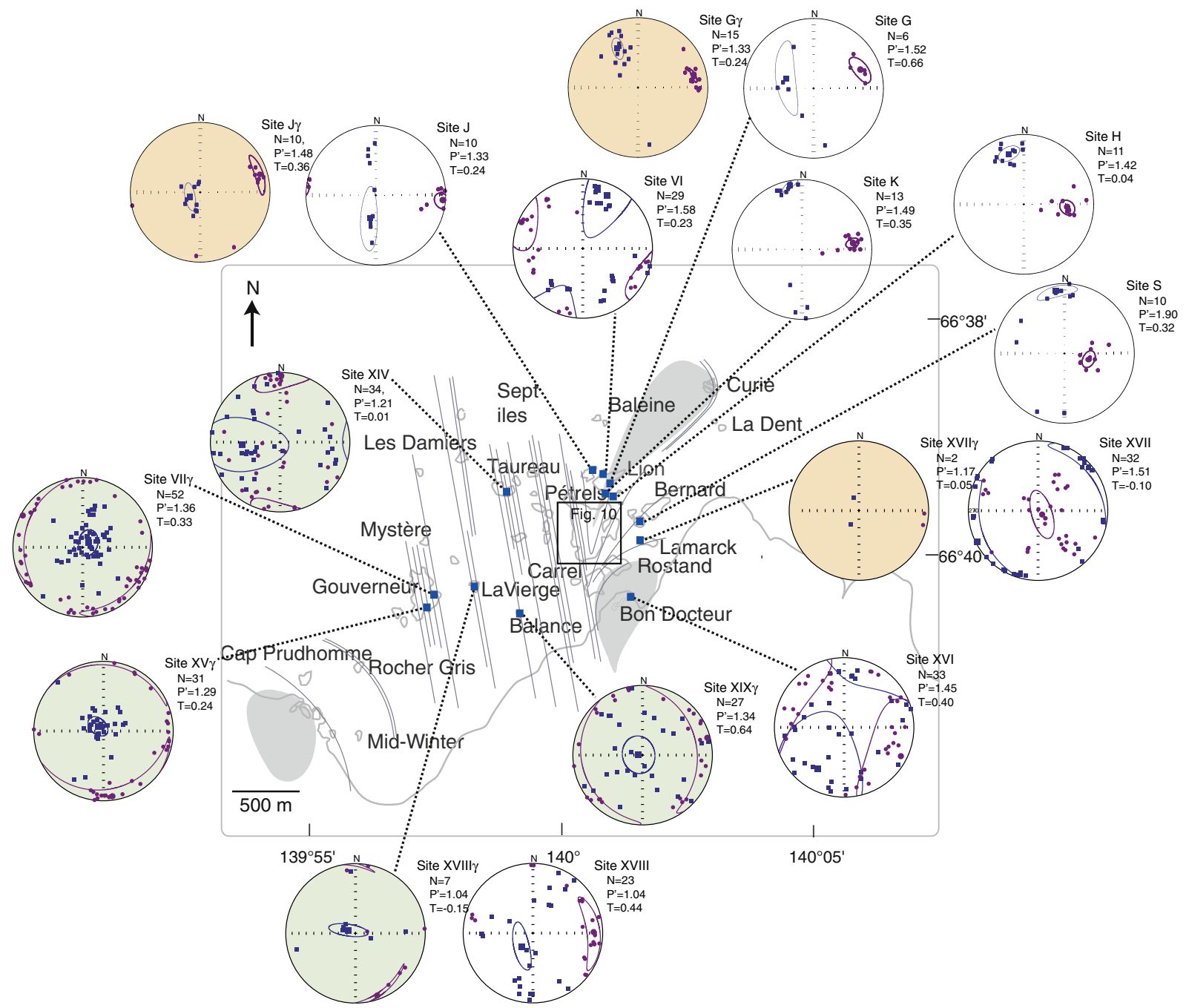

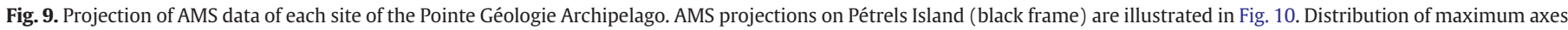

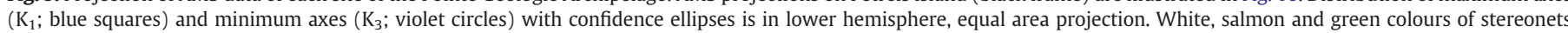
background represent the AMS projections of gneisses, granitic dykes and anatexites, respectively. 


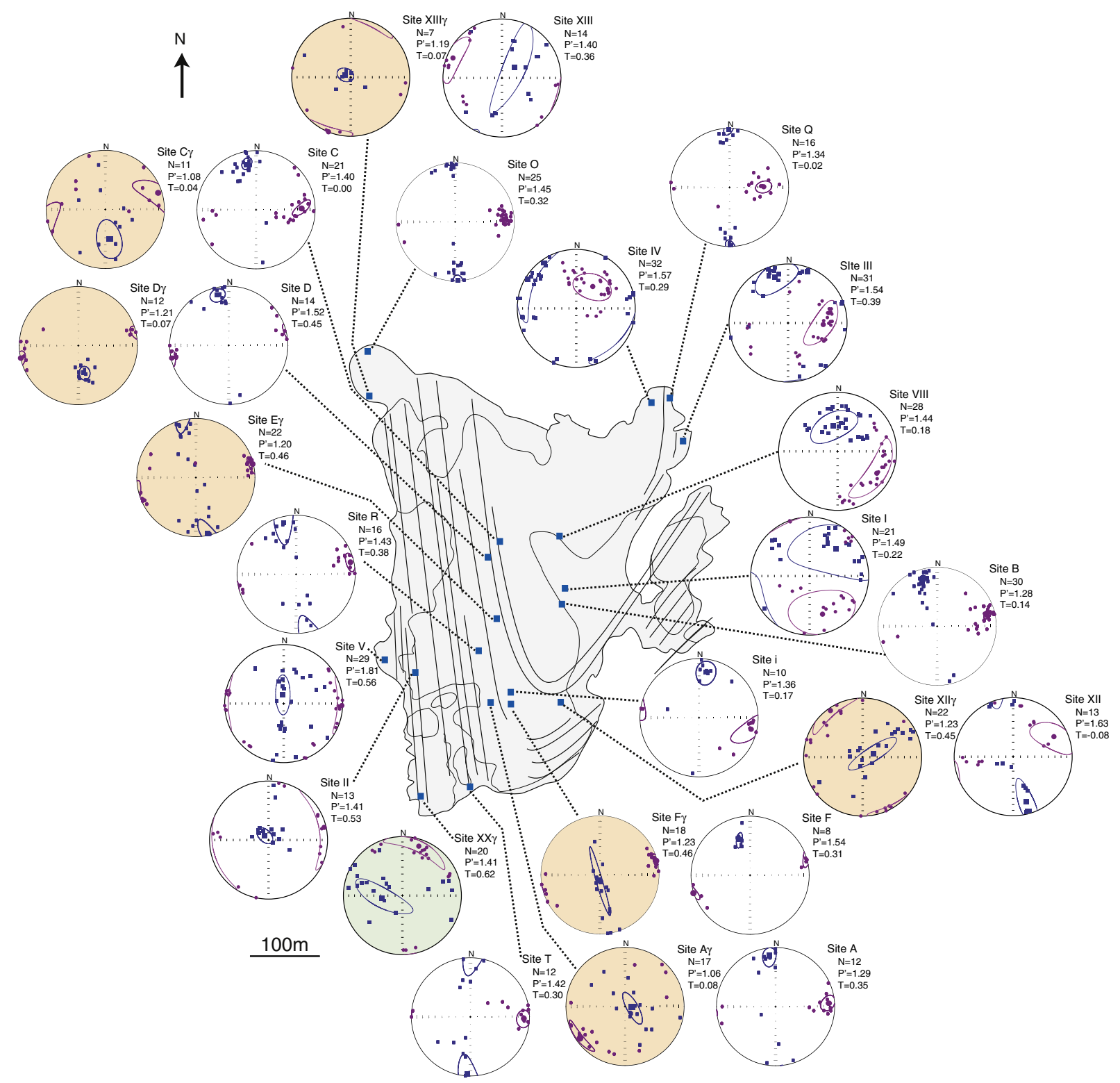

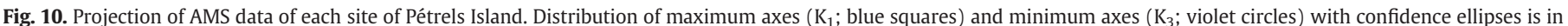

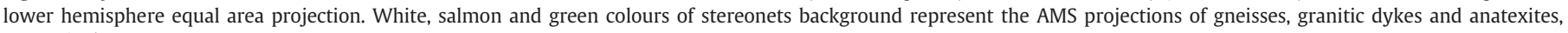
respectively.

could be explained by the lower amount of magnetite in granites, AMS then resulting mainly from strong magnetite anisotropy and weak anisotropy of a low susceptibility component. Owing to its $\mathrm{Km}$ values, this last component is the paramagnetic minerals and not the maghemite.

Inversely to granitic magmas constituting leucosomes and dykes, a wide range in $\mathrm{Km}$ values, according to samples within a single site, is observed in anatexites. It is due to the presence of more refractory gneissic rafts with high concentration in oxides grains.

\subsection{AMS in migmatitic gneisses and granites}

In addition to the $\mathrm{Km}$ and $\mathrm{P}^{\prime}$ values, the main differences in magnetic fabrics between melanosome layers of gneisses and granitic magmas concern the orientation of the $K_{1}$ axis (Figs. 9, 10 and $11 \mathrm{~b}) . \mathrm{K}_{1}$ axis is dominantly close to the horizontal in melanosomes and close to vertical in granites. In some granitic sites (e.g., sites E $\gamma$, XII $\gamma$, Fig. 10), its orientation is relatively scattered within a vertical plane, probably because of the presence of melanosome fragments within the granite. Another difference in orientation of susceptibility axes concerns $\mathrm{K}_{3}$. Whereas in melanosome the $\mathrm{K}_{3}$ orientation fits with the field structures, it appears that granites show a more complex magnetic orientation pattern with two dominant orientations. The first one matches that of the gneissic structures (for example, the magnetic foliation is vertical N-S in the shear zone area) and the second is at $90^{\circ}$ of the first one. In some sites the two clustering are present (e.g., site XV $\gamma-$ Fig. 9 and site XIII $\gamma-$ Fig. 10). The first orientation is associated to the strike-slip deformation, which is at the origin of the large-scale sub-vertical corridors. The cause of the second orientation is less straightforward. In Pétrels Island, the migmatitic layering is locally cut by vertical large granitic dykes of NE-SW to E-W direction (Monnier, 1995). Then emplacement of such E-W trend dykes is tectonically controlled and consistent with a component of NNW-SSE to N-S dextral strike-slip (Gapais et al., 2008). In the western area (Gouverneur Island area, Fig. 9) where rafts of melanocratic restites are still packed in anatexites, E-W magnetite could correspond to inheritance of older tectonic foliations. 

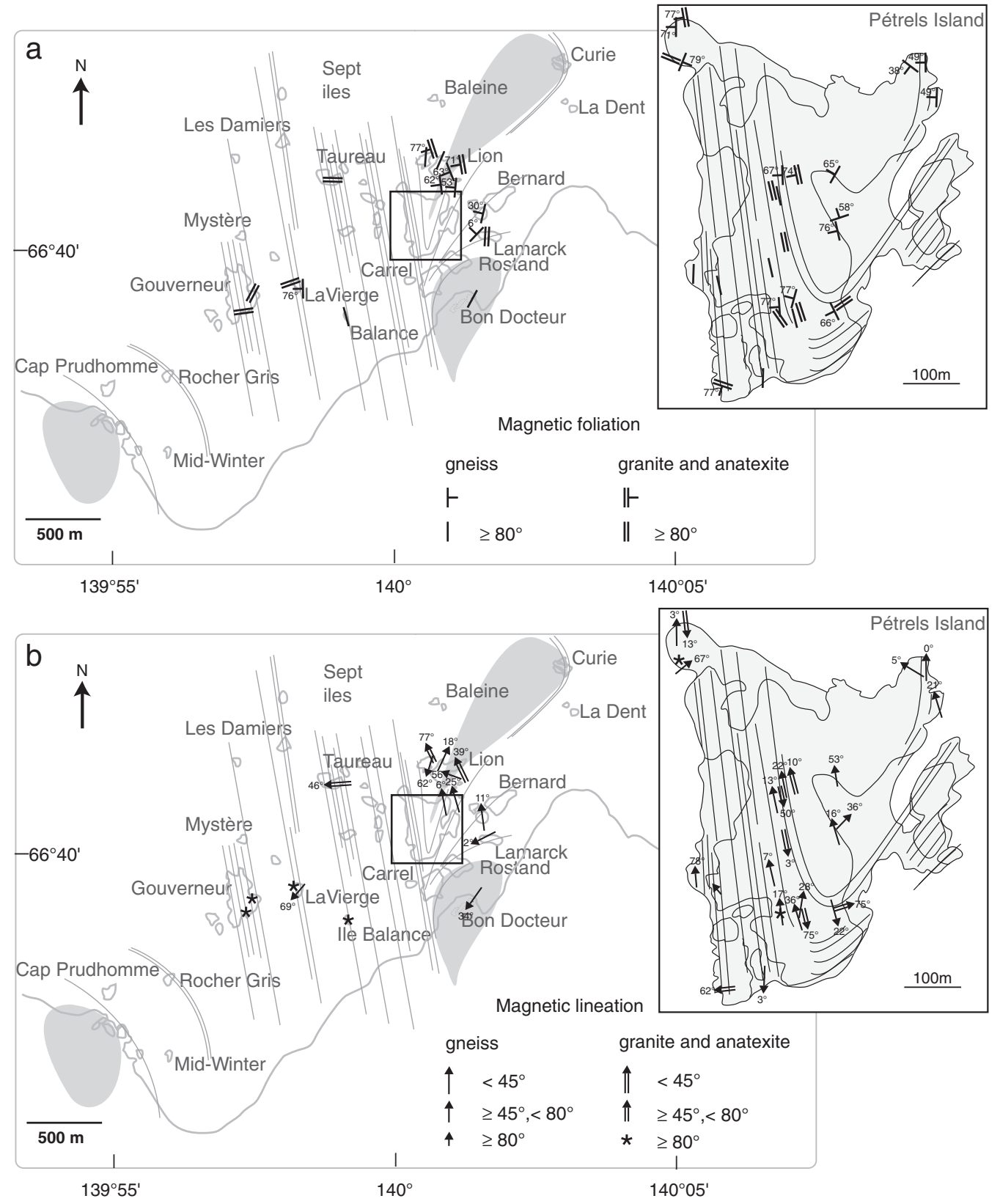

Fig. 11. Map of magnetic structures in the Pointe Géologie Archipelago: foliations (a.) and lineations (b.).

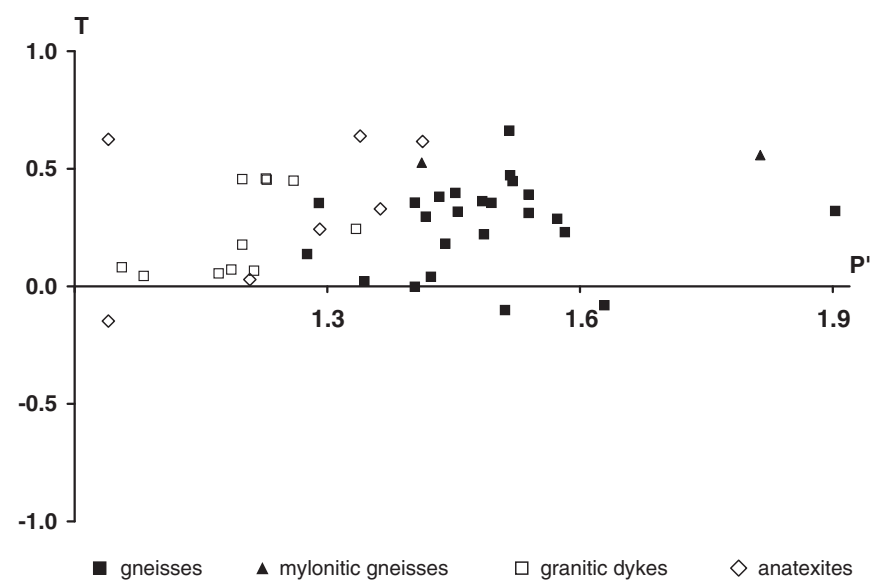

Fig. 12. T parameter as a function of $\mathrm{P}^{\prime}$ values (Jelínek, 1981) for high temperature main rock types of the Pointe Géologie archipelago.
Gneisses in sites II and V (Rocher Jakobsen), on the south-western border of the Pétrels Island also present mainly sub-vertical $K_{1}$ axes (Figs. 10 and $11 \mathrm{~b}$ ). However, they are intensely deformed, unlike the granitic leucosomes, dykes and anatexites that have not recorded pervasive solid-state deformation. Thus, AMS fabric is interpreted as resulting of high-strained, late- to post-migmatisation solid-state deformation. The strong $\mathrm{K}_{3}$ clustering indicating $\mathrm{N}-\mathrm{S}$ vertical magnetic foliation and the highly tilted to sub-vertical magnetic lineation could be related to deformation in transpression regime.

Thin section analyses show a change of orientation of magnetite grains from melanosome to leucosome. In melanosome, the oxide grains are within the foliation and elongated parallel to the lineation also marked by the sillimanite alignment mainly developed in the dome-like domains. They are interpreted as resulting from solid-state deformation that occurred during the Paleoproterozoic metamorphic event (1.69 Ga ago). In addition, LPO of ilmenite, which strongly correlated with the tectonic fabrics, suggests dislocation glide on (0001) as a main deformation mechanism. The basal slip for hematite-ilmenite 
mineral could reflect high-temperature solid-state deformation (e.g., Bascou et al., 2002; Siemes et al., 2003). Migmatitisation processes are also associated with segregation and transfer of melts that lead to leucosomes, pink granitic dykes and then anatexites when partial melting degree is higher. As discussed in Vigneresse et al. (1996) and recently in Holtzman et al. (2012), the increase of melt fraction produce changes in rheological behaviour from plastic deformation evidenced by elongation of oxide minerals that are abundant in the melanosome, to magma flow with transport of isolated solid particles in leucosomes, dykes and anatexites.

Such different and successive deformation regimes affecting magnetite grains first deformed under solid-state conditions and then involved as passive rigid particles during melting, have been already described in migmatitic terrains (e.g., Ferré et al., 2003). In the Pointe Géologie migmatites, these successive regimes generate distinctive AMS signatures. The clearest difference concerns the $K_{1}$ orientation, which tends to a vertical plunge during segregation and circulation of felsic melt pointing out a dominantly upward transport. The $\mathrm{K}_{3}$ orientation in granitic layers appears more sensitive to the degree of partial melting and the structuration of country rock. At lower degree of partial melting, liquid segregation remained strongly constrained by the framework of the unmelted gneissic material. Then the felsic melt, forming dykelets and connected lenses is concordant with the foliation of gneisses. For higher degree of melting, the melt was injected as concordant or crosscutting large veins (Fig. 2c, d) resulting in the various orientations of the magnetic foliation.

\subsection{Methodological implication}

All these observations evidence that the AMS study of migmatites cannot be considered as a routine method. To be as reliable as possible, the AMS approach requires a preliminary detailed observation of the various leucosomes habitus and then a large number of magnetic measurements of rocks characterized by various degrees of melting. For low degrees of partial melting, the leucocratic layers remain strongly constrained by the earlier structure defined by the unmelted material. In that case, the AMS principal axes are representative of the local and regional finite strain axes. This fits with the conclusions of Ferré et al. (2003) for migmatites of the Superior Province in Minnesota. For more pronounced partial melting degree, well-individualized leucocratic layers can developed specific AMS patterns associated to flow regime. In the Pointe Géologie migmatites, the difference with the local and regional finite strain axes is highlighted by the direction of $\mathrm{K}_{1}$-axes. Large variations of the partial melting rates increase the probability to measure composite AMS and the difficulty to isolate pre- and syn-melting magnetic fabrics. The strongest variations of AMS principal directions and parameters recorded in anatexites are related to the heterogeneity of these rocks, which enclose number of schlierens and refractory material.

\subsection{Regional-scale implication}

The structural pattern of Pointe Géologie consists of two domains with respectively flat-lying and sub-vertical foliations related to long-lived tectonics, metamorphic and anatectic event, both associated with partial melting (Monnier, 1995; Pelletier et al., 2002, 2005). Commonly, stretching and mineral lineations are not easy to observe within foliations, especially within the sub-vertical shear zones. Combining structural field evidences, determination of Pressure-Temperaturetime metamorphic evolution and analogue modelling of the mantlecrust ductile deformation Gapais et al. (2008) proposed a model in which the Paleoproterozoic hot and weak lithosphere converges toward a cooler and more rigid craton (Neoarchean in age). In this model, deformation of the Paleoproterozoic crust combines both transpression and horizontal flow and/or lateral escape parallel to the Archean basement and perpendicular to the shortening direction.

AMS structural pattern determination provides complementary structural information such as magnetic lineations. They are mainly sub-horizontal in sub-vertical foliated gneisses. It underlines the importance of the strike-slip component during the deformation. In mylonitic gneisses that are considered as late- to post-migmatisation tectonites, nearly vertical lineations are observed. This is considered as the effect of transpressional regime, which combines strike-slip and acrossstrike shortening. In migmatites with flat-lying foliation, the magnetic lineation displays a moderate plunge and is commonly parallel to the mineral stretching lineation. Such features are in good agreement with horizontal crustal flow mechanism.

Increasing amounts of partial melting lead to a loss of the rock cohesion related to the migration of the melt trough a solid-state made of previously deformed minerals. Thus the former tectonic structures will be progressively erased. Melt segregation and transfer occur under a viscous flow regime, mainly driven by gravity forces. In such a regime, the well-defined leucosomes, dykes and anatexites will develop a magnetic fabric corresponding to the upward transport of magmas (Fig. 13). There, AMS measurements can better map the mass transfers associated with intensive melting at peak temperatures and to characterize the general framework of a warm and buoyant lithosphere. Hence, rheological changes related to partial melting generate strain partitioning between gneisses and strongly melted rocks in a regional transpressional tectonics context.

\section{Conclusions}

Pointe Géologie archipelago in Terre Adélie represents a mid-crustal section affected by intensive anatectic processes during Paleoproterozoic

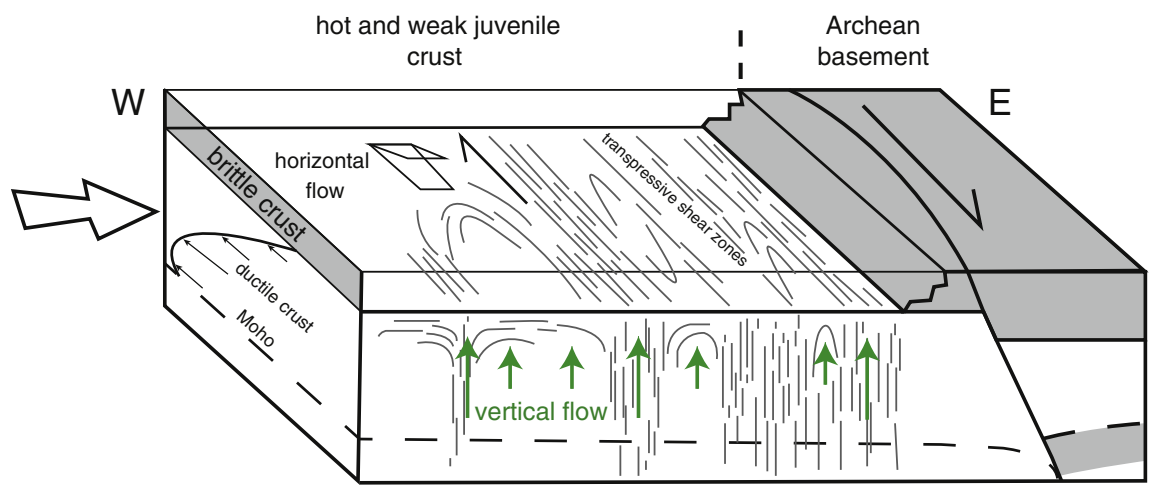

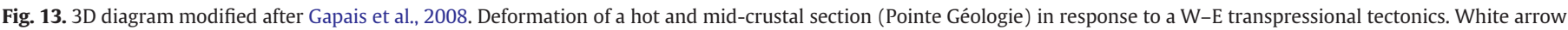

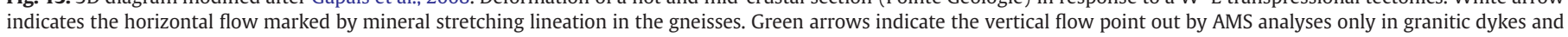
anatexites. 
times, 1.69 Ga ago. This generated different High Temperature rock types such as: migmatites including leucosomes and melanosomes, coarse-grained pink granites dyke and anatexites. Partial melting affects indifferently the regional structures characterized by the juxtaposition of flat-lying and sub-vertical deformation zones.

Magnetic mineralogy study shows that oxide minerals are mainly large and solid state deformed grains of magnetite. In the leucosomes, oxides appear more scattered than in the melanosomes and their rounded isometric shape suggests rotations of the former elongated grain during melt segregation. This contrasted magnetite grains distribution will generate specific AMS signatures for melanocratic layers on the one hand and felsic leucosomes, dykes and anatexites on the other hand. The mean magnetic susceptibility $(\mathrm{Km})$ and the anisotropy degree $\left(\mathrm{P}^{\prime}\right)$ are higher in the gneisses and much lower in granitic samples. Orientation of principal susceptibility axes also differs. In migmatitic gneisses, magnetic foliations are coherent with the local and regional structural pattern. Nevertheless AMS technique provides complementary information on the orientation of lineations when they are difficult to observe in the field. The magnetic lineations are dominantly sub-horizontal in the shear zone while they tend to be vertical in granitic dykes, anatexites and well-defined leucosomes. Such a changing of orientation is related to a rheological contrast between the solid-state deformation suffered by the oxide grains and their reorientation in a viscous flow during the aggregation of felsic melt.

Magnetic structure pattern is in good agreement with the regional tectonic framework assumed by Gapais et al. (2008). Based on metamorphic and field structural data together with analogic simulation, these authors proposed a model of deformation that implies the convergence of a hot and weak Paleoproterozoic lithosphere toward a cooler rigid Archean craton. They explained the structural pattern of the Pointe Géologie and surrounding areas by horizontal, orogen-parallel, sub-constrictional flow that could result from oblique convergence and/or from particular boundary conditions facilitating lateral escape. A comparable model was also assumed from numerical modelling to image the deformation of the hot Neoarchean crust of the Eastern part of the Terre Adélie Craton (Duclaux et al., 2007). The magnetic structures map highlights the role of the gravity-induced upwelling of a crust undergoing partial melting.

From methodological point of view, this work emphasizes on the importance of an acute petrological characterization of sites to be selected for AMS measurements in order to avoid pre- and syn-melting composite magnetic fabrics. Finally, it underlines the difficulty of AMS analyses in anatectic rocks, which lead to a very large variability for AMS signature; this mainly due by the preservation of refractory rafts and by the heterogeneity of such rocks.

\section{Acknowledgements}

We are very grateful to the French polar institute "Institut Paul Emile Victor" for support of the programme ArLiTA (Architecture de la Lithosphere de Terre Adélie) and to the Japanese "National Institute of Polar Research" for participation to the international exchange programme under the Antarctica Treaty and for invitation of BH in Tokyo. This paper has benefited of the reviews of Federico Rossetti, Fabrizio Storti and Denis Gapais.

\section{References}

Bascou, J., Raposo, M.I.B., Vauchez, A., Egydio-Silva, M., 2002. Titanohematite lattice preferred orientation and magnetic anisotropy in high-temperature mylonites. Earth and Planetary Science Letters 198, 77-92.

Bellair, P., 1961a. Pétrographie du socle cristallin de la Terre Adélie. Comptes Rendus de l'Académie des Sciences de Paris D252, 3296-3298.

Bellair, P., 1961b. Sur les formations anciennes de l'archipel de Pointe Géologie (Terre Adélie). Comptes Rendus de l'Académie des Sciences de Paris D252, 3087-3089.
Bellair, P., Delbos, L., 1962. Age absolu de la dernière granitisation en Terre Adélie. Comptes Rendus de l'Académie des Sciences de Paris D254, 1465-1466.

Borradaile, G.J., Henry, B., 1997. Tectonic applications of magnetic susceptibility and its anisotropy. Earth-Science Reviews 42, 49-93.

Borradaile, G.J., Jackson, M., 2004. Anisotropy of magnetic susceptibility (AMS), magnetic petrofabrics of deformed rocks, magnetic fabrics. Geological Society of London, Special Publication 299-360.

Charles, N., Faure, M., Chen, Y., 2009. The Montagne Noire migmatitic dome emplacement (French Massif Central): new insights from petrofabric and AMS studies. Journal of Structural Geology 31, 1423-1440.

Day, R., Fuller, M., Schmidt, V.A., 1977. Hysteresis properties of titanomagnetites: grain size and compositional dependence. Physics of the Earth and Planetary Interiors 13, 260-267.

Duclaux, G., Rey, P., Guillot, S., Ménot, R.P., 2007. Orogen-parallel flow during continental convergence: numerical experiments and Archean field examples. Geology 35, 715-718.

Fanning, C.M., Daly, S.J., Bennett, V.C., Ménot, R.P., Peucat, J.J., Oliver, R.L., Monnier, O., 1995. The "Mawson Block": once contiguous Archean to Proterozoic crust in the East Antarctic Shield and Gawler Craton, Australia. VII International Symposium on Antarctic Earth Sciences, Spec. Vol. Terra Antarctica, Siena, Italy.

Fanning, C.M., Ménot, R.P., Peucat, J.J., Pelletier, A., Fanning, C.M., Ménot, R.P., Peucat, J.J., Pelletier, A., Fanning, C.M., Ménot, R.P., Peucat, J.J., Pelletier, A., 2002. A closer examination of the direct links between Southern Australia and Terre Adélie and Georges V land, Antarctica. 16th Australian Geological Congress, AGC, Adélaïde Australia.

Ferré, E., Teyssier, C., Jackson, M., Thill, J.W., Rainey, E., 2003. Magnetic susceptibility anisotropy: a new petrofabric tool in migmatites. Journal of Geophysical Research 108 (B2), 20086-20100.

Gapais, D., Pelletier, A., Ménot, R.P., Peucat, J.J., 2008. Paleoproterozoic tectonics in the Terre Adélie Craton (East Antarctica). Precambrian Research 162, 531-539.

Graham, J.W., 1954. Magnetic susceptibility anisotropy: an unexploited element of petrofabric. Geological Society of America Bulletin 65, 1257-1258.

Hasalovà, P., Schulmann, K., Lexa, O., Štipskà, P., Hrouda, F., Ulrich, S., Haloda, J., Týcovà P., 2008. Origin of migmatites by deformation-enhanced melt infiltration of orthogneiss: a new model based on quantitative microstructural analysis. Journal of Metamorphic Geology 26, 29-53.

Henry, B., Merabet, N., Derder, M.E.M., Bayou, B., 2004. Chemical remagnetizations in the Illizi basin (Saharan craton, Algeria) and their acquisition process. Geophysical Journal International 156, 200-212.

Hext, G., 1963. The estimation of second-order tensors, with related tests and designs. Biometrika 50, 353.

Holtzman, B.K., King, D.S.H., Kohlstedt, D.L., 2012. Effects of stress-driven melt segregation on the viscosity of rocks. Earth and Planetary Science Letters 359-360, 184-193.

Jelínek, V., 1978. Statistical processing of anisotropy of magnetic susceptibility measured on groups of specimens. Studia Geophysica et Geodaetica 22, 50-62.

Jelínek, V., 1981. Characterization of the magnetic fabrics of rocks. Tectonophysics 79, 63-67.

Kratinová, Z., Schulmann, K., Edel, J.-B., Tabaud, A.-S., 2012. AMS record of brittle dilation, viscous-stretching and gravity-driven magma ascent in area of magma-rich crustal extension (Vosges Mts., NE France). International Journal of Earth Sciences $101,803-817$.

Kruckenberg, S.C., Ferré, E.C., Teyssier, C., Vanderhaeghe, O., Whitney, D.L., Seaton, N.C.A., Skord, J.A., 2010. Viscoplastic flow in migmatites deduced from fabric anisotropy: an example from the Naxos dome, Greece. Journal of Geophysical Research 115, B09401. http://dx.doi.org/10.1029/2009jb007012.

Ménot, R.P., Duclaux, G., Peucat, J.J., Rolland, Y., Guillot, S., Fanning, C.M., Bascou, J., Gapais, D., Pêcher, A., Ménot, R.P., Duclaux, G., Peucat, J.J., Rolland, Y., Guillot, S Fanning, C.M., Bascou, J., Gapais, D., Pêcher, A., 2007. Geology of the Terre Adélie Craton (135-146 E). Antarctica: A Keystone in a Changing World: USGS Open-file Report 2007-1047, Short Paper 048. http://dx.doi.org/10:3133/of2007-1047.spr048 (5 pp.).

Monnier, O., 1995. Le socle protérozoïque de Terre Adélie (Antarctique Est): son évolution tectonométamorphique et sa place dans les reconstitutions du protogondwana. PhD Thesis Université Jean Monnet, Saint-Etienne.

Monnier, O., Ménot, R.P., Peucat, J.J., Fanning, M., Giret, A., 1996. Actualisation des données géologiques sur Terre Adélie (Antarctique Est): mise en évidence d'un collage tectonique au Protérozoïque. Comptes Rendus de l'Académie des Sciences de Paris 322, 55-62.

Pelletier, A., Gapais, D., Ménot, R.P., Peucat, J.J., 2002. Tectonique transpressive en Terre Adélie au Paléoprotérozoïque (East Antarctica). Comptes Rendus de l'Académie des Sciences de Paris 334, 505-511.

Pelletier, A., Guiraud, M., Ménot, R.P., 2005. From partial melting to retrogression in the Pointe Geologie migmatitic complex: a history of heterogeneous distribution of fluids. Lithos 81, 153-166.

Peucat, J.J., Ménot, R.P., Fanning, C.M., 1999. The Terre Adélie basement in the EastAntarctica Shield: geological and isotopic evidence for a major $1.7 \mathrm{Ga}$ thermal event; comparison with the Gawler Craton in south Australia. Precambrian Research 94, 205-224.

Potter, D.K., Stephenson, A., 1988. Single domain particles in rocks and magnetic fabric analysis. Geophysical Research Letters 15, 1097-1100.

Prior, D.J., Boyle, A.P., Brenker, F., Cheadle, M.C., Day, A., Lopez, G., Peruzzo, L., Potts, G.J. Reddy, S., Spiess, R., Timms, N.E., Trimby, P., Wheeler, J., Zetterström, L., 1999. The application of electron backscatter diffraction and orientation contrast imaging in the SEM to textural problems in rocks. American Mineralogist 84, 1741-1759.

Rochette, P., Jackson, M., Aubourg, C., 1992. Rock magnetism and the interpretation of anisotropy of magnetic susceptibility. Reviews of Geophysics 30, 209-226. 
Schulmann, K., Edel, J.B., Hasalová, P., Cosgrove, J., Jések, J., Lexa, O., 2009. Influence of melt induced mechanical anisotropy on the magnetic fabrics and rheology of deforming migmatites, Central Vosges, France. Journal of Structural Geology 31, 1223-1237.

Siemes, H., Klingenberg, B., Rybacki, E., Naumann, M., Schäfer, W., Jansen, E., Rosière, C.A 2003. Texture, microstructure, and strength of hematite ores experimentally deformed in the temperature range $600-1100{ }^{\circ} \mathrm{C}$ and at strain rates between $10^{-4}$ and $10^{-6} \mathrm{~s}^{-1}$. Journal of Structural Geology 25, 1371-1391.

Tarling, D.H., Hrouda, F., 1993. The Magnetic Anisotropy of RocksFirst edition. Chapman and Hall, London (1993 ed.).
Viegas, L.G.F., Archajo, C.J., Vauchez, A., 2013. Fabrics of migmatites and the relationships between partial melting and deformation in high-grade transpressional shear zones: the Espinho Branco anatexite (Borborema Province, NE Brazil). Journal of Structural Geology 48, 45-56.

Vigneresse, J.L., Barbey, P., Cuney, M., 1996. Rheological transitions during partial melting and crystallisation with application to felsic magma segregation and transfer. Journal of Petrology 57, 1579-1600.

Wimmenauer, W., Bryhni, I., 2007. Migmatites and related rocks. In: IUGS (Ed.), Metamorphic Rocks: A Classification and Glossary of Terms. Cambridge University Press, New York, pp. 43-45. 